\title{
Mineralogical study on volcanic ash of the eruption on September 27, 2014 at Ontake volcano, central Japan: correlation with porphyry copper systems
}

\author{
Yusuke Minami ${ }^{i^{*}}$, Takumi Imura', Shintaro Hayashi ${ }^{2}$ and Tsukasa Ohba ${ }^{3}$
}

\begin{abstract}
The volcanic ash of the eruption on September 27, 2014 at Ontake volcano consists mostly of altered rock fragments. The ash contains partly altered volcanic rock fragments consisting of primary igneous minerals (plagioclase, orthopyroxene, titanomagnetite, and feldspars) and volcanic glass accompanied by alteration minerals to some extents, and contains no juvenile fragments. These features indicate that the eruption was a non-juvenile hydrothermal eruption that was derived from the hydrothermal system developed under the crater. The major minerals derived from hydrothermal alteration zones are silica mineral, kaolin-group mineral, smectite, pyrophyllite, muscovite, alunite, anhydrite, gypsum, pyrite, K-feldspar, albite, and rutile. Minor chlorite, biotite, and garnet are accompanied. Five types of alteration mineral associations are identified from observations on individual ash particles: silica-pyrite, silica-pyrite \pm alunite \pm kaolin, silica-pyrophyllite-pyrite, silica-muscovite \pm chlorite, and silica-K-feldspar \pm albite \pm garnet \pm biotite. The associations indicate development of advanced argillic, sericite, and potassic alteration zones under the crater. Occurrence of anhydrite veinlet and the set of alteration zones indicate hydrothermal alteration zones similar to late-stage porphyry copper systems. Comparing the mineral associations with the geologic model of the late-stage porphyry copper systems, the source depths of mineral associations are estimated to range from near surface to $>2 \mathrm{~km}$. The depths of advanced argillic alteration, sericite, and potassic zones are 0 to $\sim 2, \sim 1.5$ to $\sim 2$, and $>2 \mathrm{~km}$, respectively.
\end{abstract}

Keywords: Hydrothermal eruption, Volcano-hydrothermal system, Acid-sulfate hydrothermal system, Ontake volcano

\section{Background}

The zonation of alteration minerals produced in a hydrothermal system reflects spatial variations in hydrothermal processes and hydrothermal fluid chemistry (e.g., Meyer and Hemley 1967; Rose and Burt 1979; Reed 1997). The relation between the distribution of hydrothermal fluid and consequent mineralogical zonation has been intensively studied through geological studies on geothermal fields as well as ore deposits. Some of the fields are considered to be the interior of ancient stratovolcanoes, and

\footnotetext{
*Correspondence: d9514007@wm.akita-u.ac.jp

${ }^{1}$ Graduate School of Engineering and Resource Science, Akita University,

1-1, Tegata Gakuenmachi, Akita 010-8502, Japan

Full list of author information is available at the end of the article
}

their structural models have been well established (e.g., Meyer and Hemley 1967; Sillitoe and Gappe Jr 1984; Sillitoe 2000, 2010; Hedenquist et al. 2000). Although the depths of hydrothermal systems are largely inaccessible under active volcanoes, we are able to obtain minerals precipitated at the depths when a hydrothermal eruption supplies them from the depths to the earth surface (Hedenquist and Henley 1985).

Volcanic ash from the eruption at Ontake volcano on September 27, 2014 consists abundantly of hydrothermally altered minerals (Miyagi et al. 2014), indicating the eruption was a hydrothermal eruption. The minerals were derived from the subvolcanic hydrothermal system under the volcano, and therefore, the properties of hydrothermal alteration such as temperature, acidity, and locus 
can be estimated from the mineralogy of the volcanic ash. This study aims to estimate the chemical conditions and locus of the source fluid by correlating the mineralogy of the volcanic ash to proposed models of mineral zonation in well-studied ancient hydrothermal systems beneath eroded old volcanoes. The estimation on the locus will be compared with previous geophysical estimations (Kato et al. 2015; Maeda et al. 2015).

\section{Geological setting of Ontake volcano}

Ontake volcano (3067 MASL) located in central Japan is a stratovolcano consisting of basalt, andesite, and dacite. The basement of Ontake volcano is largely composed of Jurassic to Paleogene rhyolite to rhyodacite and marine sediments (Yamada and Kobayashi 1988; Takeuchi et al. 1998). Volcanic activity at Ontake volcano commenced 200-300 ka with effusion of basaltic to andesitic lava flows with minor dacite to form the ancestral volcanic edifice (Yamada and Kobayashi 1988). The younger activity that formed the current edifice commenced at $80 \mathrm{ka}$. The activity is subdivided into two stages: the early explosive stage that produced rhyolitic to dacitic pyroclasts and the later lava stage. The lava is composed of andesite containing phenocrysts of plagioclase, orthopyroxene, clinopyroxene, and magnetite. The summit area at Kengamine is composed of andesite lava (Yamada and Kobayashi 1988).

Phreatic (or hydrothermal) eruptions frequently occur at Ontake volcano. Before the 2014 eruption, at least three phreatic eruptions were documented in 1979, 1991, and 2007 (Oikawa et al. 2014). Oikawa et al. (2014) suggested that the frequency of phreatic eruptions of Ontake volcano is at least once in a few 100 years. Surface hydrothermal manifestations have been continuously observed on the southwestern flank of Kengamine cone for last 250 years (Oikawa 2008). Hydrothermally altered rocks had been exposed on the southwestern flank of Kengamine before the 2014 eruption.

\section{The 2014 eruption}

The 2014 eruption took place on September 27th on the southwestern flank of Kengamine. The eruption ejected approximately a million tons of volcanic ash, similar to the volume of the 1979 eruption (Takarada et al. 2014), and the Volcanic Explosively Index (VEI) of the 2014 eruption was two (Earthquake Research Institute at the University of Tokyo 2014; Japan Meteorological Agency 2014). The volcanic ash was distributed in the summit area and on the eastern flank of the volcano (Fig. 1; Nakano et al. 2014; Takarada et al. 2014). Miyagi et al. (2014) reported that the volcanic ash consists exclusively of hydrothermally altered minerals with minor primary igneous particles. Some geophysical studies have reported analyses on seismicity linked to the eruption, investigating pre- and post-eruptive processes (e.g., Kato et al. 2015; Maeda et al. 2015; Ogiso et al. 2015).

\section{Sampling and methods}

The volcanic ash from the September 27, 2014 eruption was sampled along a road $8 \mathrm{~km}$ northeast of the vent (Fig. 1). Particles were separated into three fractions: coarse $(>125 \mu \mathrm{m})$, medium $(125-70 \mu \mathrm{m})$, and fine $(<70 \mu \mathrm{m})$ fractions. The samples were analyzed with X-ray diffractometer (XRD) and SEM-EDS. Bulk ash samples were also analyzed by XRD.

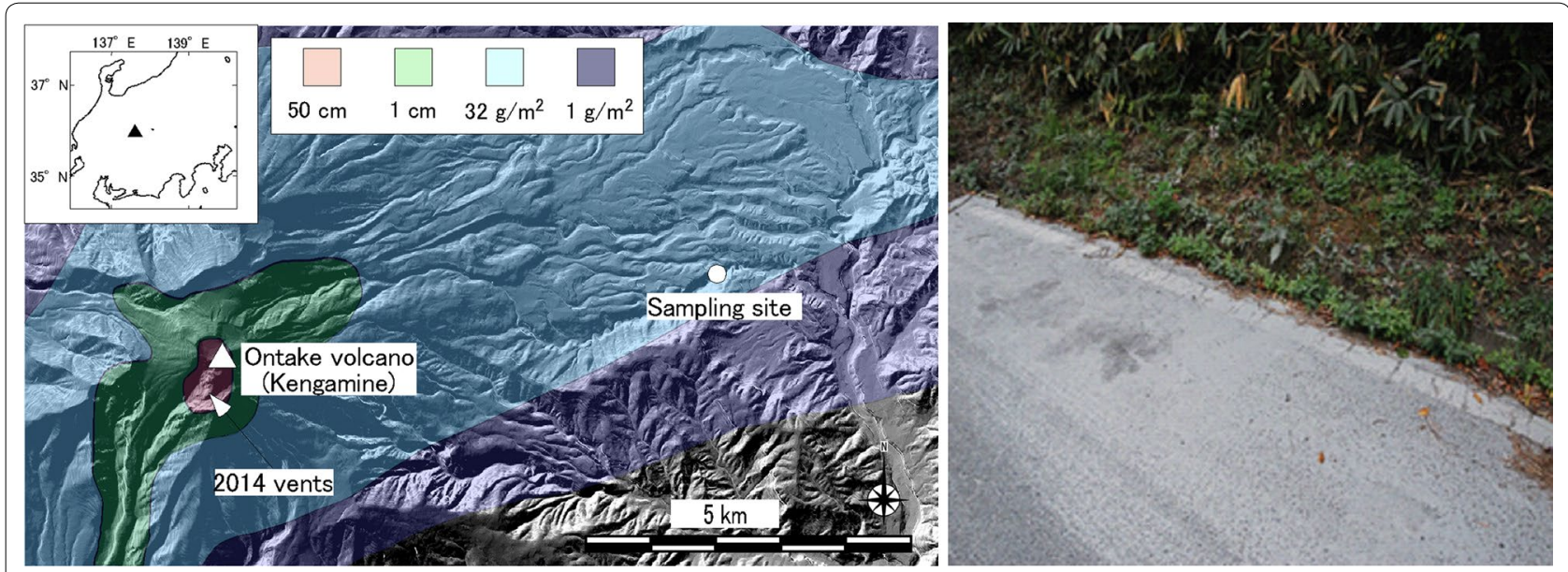

Fig. 1 Location of sampling site (left) and volcanic ash from the eruption (right). Volcanic ash was sampled along the road. The samples were collected from clean, flat, and hard surface of the road and also from clean leaves. The volcanic ash distribution is drawn based on Takarada et al. (2014). The topographic relief map is created with Kasimir3D (Sugimoto 2016) from the 10-m-mesh DEM data provided by the Geospatial Information Authority of Japan 
Table 1 Minerals in the volcanic ash of the 2014 eruption at Ontake volcano

\begin{tabular}{|c|c|c|c|c|c|c|c|c|c|c|c|c|c|}
\hline Fraction & Qtz & Crt & Trd & Fsp & Smct & Opx & Mica & Pyl & Kao & Pyr & Alu & Anh & Gyp \\
\hline Bulk & $* * *$ & $* *$ & $f$ & $* *$ & $f$ & $* * *$ & $f$ & $f$ & $*$ & $*$ & $* * *$ & $f$ & $* *$ \\
\hline Coarse & $* * *$ & $* * *$ & * & $* *$ & $f$ & $* * *$ & $f$ & $f$ & $*$ & $* * *$ & $*$ & $f$ & * \\
\hline Medium & $* * *$ & $* *$ & $f$ & $* * *$ & $f$ & & $f$ & $f$ & $* * *$ & $* *$ & $* *$ & $* * *$ & * \\
\hline Fine & $* * *$ & $f$ & & & $* *$ & $f$ & $* *$ & $f$ & $* * *$ & $f$ & $* * *$ & & $* * *$ \\
\hline
\end{tabular}

The minerals are: Qtz: quartz, Crt: cristobalite, Trd: tridymite, Fsp: feldspars, Smct: smectite, Opx: orthopyroxene, mica: mica minerals, Pyl: pyrophyllite, Kao: $7 \AA$-kaolingroup mineral, Pyr: pyrite, Alu: alunite, natroalunite and minamiite, Ahd: anhydrite, and Gyp: gypsum

The intensities of X-ray peaks in the XRD analysis are shown as: ${ }^{* *}$ intense; ${ }^{* *}$ weak; ${ }^{*}$ minor; f: faint and blank none

Minerals were identified with the XRD (Multiflex; Rigaku Corp.) installed at Akita University. Measurements were carried out at a rate of $1^{\circ}$ per minute from $2^{\circ}$ to $60^{\circ}$ using a $\mathrm{CuK} \alpha$ target $\mathrm{X}$-ray tube with an acceleration voltage of $30 \mathrm{kV}$ and a filament current of $16 \mathrm{~mA}$. A randomly oriented sample and an oriented sample were prepared for each fraction. Ethylene glycol and $\mathrm{HCl}$ treatments were applied to all fractions to determine clay mineral species.

The mineralogy of individual ash particles was investigated by stereoscopic microscope observation (on particles $>125 \mu \mathrm{m}$ ) and SEM-EDS semiquantitative analysis focusing on textures, shapes, color, and chemical composition. The ash morphology was observed using stereoscopic microscope and a scanning electron microscope (SEM, JSM-6610LV with a tungsten filament; JEOL Co.) at Akita University. Semiquantitative microprobe analysis was carried out with an energy-dispersive X-ray spectroscopy (EDS, INCA X-act; Oxford Instruments) attached to the SEM. Semiquantitative analysis was carried out at an acceleration voltage of $15 \mathrm{kV}$, a probe current of $2.2 \mathrm{nA}$, a working distance of $10 \mathrm{~mm}$, and a live time of $20 \mathrm{~s}$. Polished sections were prepared for the SEM-EDS observation on the coarse and medium fractions. Atomic proportions measured by SEM-EDS semiquantitative analysis were used to specify mineral species combined with XRD measurement on bulk samples. Analytical accuracy and precision of the semiquantitative SEM-EDS analysis were reported by Ohba et al. (2011), indicating precisions less than $0.3 \mathrm{wt} \%$ and consistency with WDS analysis for major elements in plagioclase, olivine, and pyroxenes.

\section{Results}

\section{Minerals in the ash}

Minerals identified in the ash are listed in Table 1. The XRD measurement elucidated that smectite, pyrophyllite, mica, a 7-Å kaolin-group mineral (any of kaolinite, nacrite, or dickite), quartz, cristobalite, alunite, gypsum, and pyrite occur in all fractions. The X-ray peaks of quartz, 7- $\AA$ kaolin-group minerals, alunite, and gypsum are sharp, and their intensities are high in both fractions. Feldspar and anhydrite only occur in the course and the medium fractions. The intensities of X-ray peaks of the sheet silicate minerals are higher in the fine fraction than in other fraction.

SEM-EDS microprobe analysis was carried out to identify mineral species in individual grains of the medium and coarse fractions. There is no mineralogical difference between the coarse and medium fractions except for the presence of calcium sulfate minerals in the medium fraction. Each ash grain consists mostly of multiple mineral crystals ranging from submicron to millimeter in size. The EDS analysis on very fine crystals sometimes yields confusing results because the induced X-rays from adjacent crystals affect those of the target crystal (e.g., analysis on a mixture of fine crystals of quartz and kaolin may result in deceptive composition similar to pyrophyllite). To reduce this effect, only crystals that are compositionally and texturally homogeneous were analyzed. Some grains exhibit apparently homogeneous textures, although these consist of very fine crystals (smaller than the resolution of the image). The compositional homogeneity was examined by repeating the analysis on multiple positions in the grain. If a grain that is even apparently homogeneous is a mixture of different fine crystals, elemental proportion arbitrarily changes by position.

The following minerals were identified with SEM-EDS based on stoichiometric relations: Silica mineral $\left(\mathrm{SiO}_{2}\right)$, pyrite $\left(\mathrm{FeS}_{2}\right)$, and alunite $\left[(\mathrm{Na}, \mathrm{K}) \mathrm{Al}_{3}\left(\mathrm{SO}_{4}\right)_{2}(\mathrm{OH})_{6}\right]$ were determined simply on the basis of analytical values close to these ideal chemical formulae. Here, we use the term "silica mineral" because identification of silica polymorphs is often impossible with EDS analysis. Fine alunite crystals interweaved with silica mineral show spectra imposed by Si peaks, which can be still identified as the mixture of these minerals based on their distinct elemental proportions. Similarly, rutile that occurs as tiny crystals mixed with silica minerals is identified from distinct titanium spectra accompanied by silica peaks with arbitrarily changing intensity. As two types of calcium sulfate minerals were identified with XRD, gypsum and 
anhydrite are distinguished by the oxygen/sulfur ratio. Feldspar, pyroxene, and garnet were identified with stoichiometric proximities between the ideal formulae and the analytical results. Results for the very fine feldspar yielded X-ray spectra influenced by juxtaposed crystals, resulting in discrepancy from the ideal formula, and were discarded. Spectra with $\mathrm{SiO}_{2}$ and $\mathrm{Al}_{2} \mathrm{O}_{3}$ indicate the presence of hydrous aluminous silicate mineral (either pyrophyllite or kaolin-group minerals). Pyrophyllite consists mostly of $\mathrm{Al}_{2} \mathrm{O}_{3}$ and $\mathrm{SiO}_{2}$ and the atomic concentration of $\mathrm{Si}$ is twice that of $\mathrm{Al}$. It contains minor amounts $(<2 \mathrm{wt} \%)$ of $\mathrm{MgO}, \mathrm{K}_{2} \mathrm{O}, \mathrm{FeO}$, and $\mathrm{CaO}$. Kaolin-group mineral is characterized by the chemical formula wherein the atomic concentrations of $\mathrm{Si}$ and $\mathrm{Al}$ are the same. Kaolin frequently occurs as very fine crystals inwrought with silica mineral, resulting in a deceptive spectrum with higher silica concentration than kaolin. The spectra were identified as a mixture of silica and kaolin when multiple analyses on different position yielded varying $\mathrm{Al} / \mathrm{Si}$ ratios which can exceed 0.5. Chlorite was identified from spectra comprising distinct $\mathrm{Si}, \mathrm{Al}, \mathrm{Mg}$, Fe peaks and negligible peaks of $\mathrm{Na}, \mathrm{K}, \mathrm{Ca}$ if the total of cations is 20 when the number of oxygen is assumed to be 28. Mica minerals are characterized by an abundance of $\mathrm{SiO}_{2}, \mathrm{Al}_{2} \mathrm{O}_{3}$, and $\mathrm{K}_{2} \mathrm{O}$ and can be distinguished from potassium feldspar by their stoichiometry. Mica was identified when the mineral has two potassium when oxygen number is assumed to be 22. Muscovite is the most common mica mineral in the sample. The simple chemical formula of muscovite is $\mathrm{KAl}_{2}\left(\mathrm{Si}_{3} \mathrm{Al}\right) \mathrm{O}_{10}(\mathrm{OH})_{2}$, in which potassium can be partly replaced by sodium and calcium, and the octahedral aluminum by iron, manganese, magnesium, and titanium. Mica mineral rich in Fe and Mg is regarded as biotite.

\section{Mineralogy and petrography of individual ash grain}

Ash grains in the coarse fraction have various appearances under a binocular microscope: opaque whitecolored grains, opaque gray-colored grains, translucent brownish gray-colored grains, translucent white-colored grains, transparent grains, and free crystals (Fig. 2). Various kinds of altered rock fragments were observed with SEM-EDS. The ash grains are classified into seven types according to mineral assemblages: partly altered volcanic rock fragment, silica mineral-pyrite, silica mineralpyrite \pm alunite \pm kaolin-group mineral, silica mineralpyrophyllite-pyrite, silica mineral-pyrophyllite-pyrite, silica mineral-muscovite, silica mineral-K-feldspar \pm albite \pm garnet \pm biotite, and crystals of pyrite, anhydrite, and gypsum (Table 2). The complete table of the mineral assemblages is included in the supplemental material (Additional file 1).

\section{Partly altered volcanic rock fragment}

Partly altered volcanic fragments are common in the ash, occurring as angular to subangular blocky fragments of partly altered volcanic rocks and minerals comprised of plagioclase, orthopyroxene, and magnetite. The partly altered rock fragments preserve the texture of volcanic rocks containing volcanic glass. Isolated crystals of plagioclase and orthopyroxene are inferred to be derived from volcanic rocks because they contain glass inclusions.
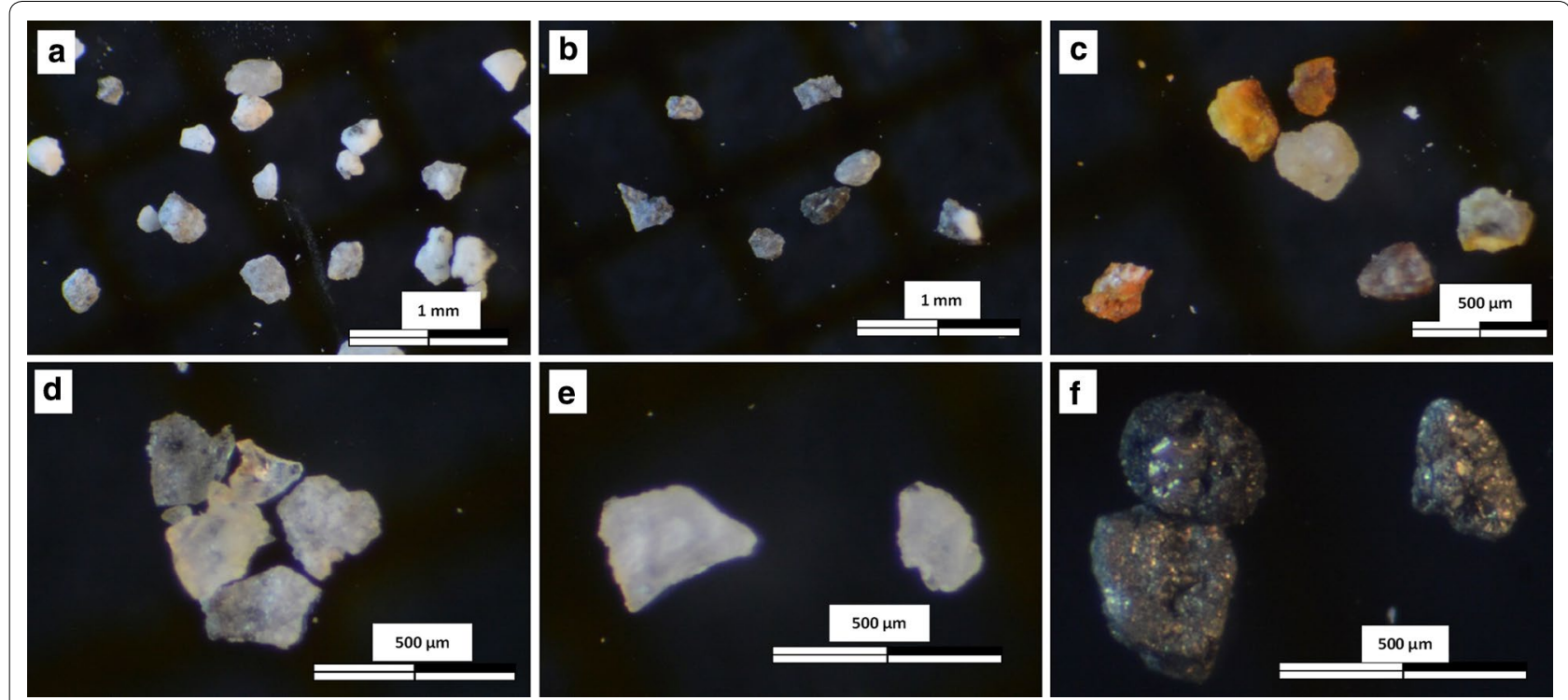

Fig. 2 Photographs of ash particles from the September 27, 2014 eruption. a Opaque white-colored grains, b opaque gray-colored grains, c translucent brownish gray-colored grains, $\mathbf{d}$ transparent grains, e translucent white-colored grains, and $\mathbf{f}$ free crystals of pyrite 
Table 2 Mineral assemblages of altered rock fragments in the volcanic ash

\begin{tabular}{|c|c|c|c|c|c|c|c|c|c|c|c|c|c|c|c|c|c|c|c|}
\hline \multirow[t]{2}{*}{ Sample name } & \multicolumn{17}{|c|}{ Mineral assemblages ${ }^{a}$} & \multirow[t]{2}{*}{ Alteration $^{\mathbf{b}}$} & \multirow[t]{2}{*}{ Colorc } \\
\hline & $\mathrm{Si}$ & $\mathrm{Ab}$ & Kfs & Kao & Mus & Pyl & Alu & Anh & Pyr & Chr & Rul & $\mathrm{PI}$ & Ano & $\mathbf{P x}$ & $\mathrm{Bi}$ & Grt & glass & & \\
\hline 141014 coarse-6 & * & & & $*$ & & & & & $*$ & & & $*$ & * & $*$ & & & $*$ & Partly & nd \\
\hline Med3-4-7 & & & * & & & & & & & & & $*$ & & & & & & Partly & nd \\
\hline Coase-1 & $*$ & & & & & & & & * & & * & & & & & & & RS & OW \\
\hline Coarse-11 & * & & & & & & & & & & * & & & & & & & RS & OG \\
\hline Coarse-18 & * & & & & & & & & * & & * & & & & & & & RS & $\operatorname{Tr}$ \\
\hline Coarse-2 & * & & & $*$ & & & & & $*$ & & & & & & & & & $\mathrm{AA}$ & OW \\
\hline Coarse-12 & $*$ & & & $*$ & & & $*$ & & $*$ & & & & & & & & & AA & OW \\
\hline Coarse-13 & $*$ & & & * & & & & & * & & & & & & & & & $\mathrm{AA}$ & OG \\
\hline Coarse-14 & $*$ & & & & & & $*$ & & $*$ & & & & & & & & & AA & OG \\
\hline Coarse-16 & $*$ & & & & & * & & & * & & & & & & & & & AA & OG \\
\hline Coarse-17 & * & & & & & * & & & * & & & & & & & & & $\mathrm{AA}$ & $\operatorname{Tr}$ \\
\hline Coarse-4 & $*$ & & $*$ & & $*$ & & & & & $*$ & & & & & & & & Ser & TBG \\
\hline 160223 Coarse 4-3 & $*$ & & & & * & & & & * & & & & & & & & & Ser & OW \\
\hline Coarse-6 & $*$ & $*$ & * & & & & & & & & & & & & & & & PA & TW \\
\hline Med3-5-10 & & $*$ & $*$ & & & & & * & & & & & & & $*$ & & & PA & nd \\
\hline Med 1-2 & $*$ & & * & & & & & & * & & & & & & & * & & PA & nd \\
\hline
\end{tabular}

a Mineral names are abbreviated as: Si: silica mineral, Ab: albite, Kfs: potassic feldspar, Kao: 7 A-kaolin-group mineral, Mus: muscovite, Pyl: pyrophyllite, Alu: alunite, Anh: anhydrite, Pyr: pyrite, Chr: chlorite, Rul: rutile, PI: plagioclase, Ano: anorthoclase, Px: pyroxene, Bi: biotite, and Grt: garnet

b Partly: partly altered volcanic rock; RS: residual silica; AA: advanced argillic; Ser: sericite; PA: potassic alteration

c OW: opaque white-colored; OG: opaque gray-colored; TW: translucent white-colored; TBG: translucent brownish gray-colored; Tr: transparent; nd: no data

Volcanic rocks of the cone are the source of the minerals, which contain them as phenocrysts (Yamada and Kobayashi 1988). Two types of groundmass-derived fragments were identified: one consisting of abundant volcanic glass and minor microlites of plagioclase and pyroxene that form hyalo-ophitic texture, and the other one consisting of microlites of plagioclase, anorthoclase, and sanidine, and minor interstitial glass that form hyalopilitic texture (Fig. 3a). The original igneous minerals and glass are partly replaced by pyrite, silica mineral, kaolingroup mineral, and muscovite.

\section{Silica mineral-pyrite}

This association consists dominantly of silica mineral, subordinate pyrite, and minor rutile. Grains of this association are abundant in the ash. They appear opaque white under a binocular microscope. This association includes various textures: pseudomorphic replacement of original volcanic rock textures (Fig. 3b), colloform texture, and mosaic texture. The grains are composed of silica minerals, minor pyrite, and rutile. The pseudomorphic textured grains preserve the original volcanic rock textures, although the original minerals have been completely replaced, mostly by silica mineral. The grains are rich in voids that are spherical, tabular, veinlet, and irregular in shape. The voids range from submicron to hundreds of $\mu \mathrm{m}$ in size, and small voids often form spongy textures. Pyrite crystals frequently fill the voids and the cleavage of the pseudomorphs of phenocrysts (Fig. 3b, c).

The pores in the highly porous grains are spherical, tabular, vein-like and irregular in shape and range from several hundred to just a few micrometers (Fig. 3c). The spherical pores are larger than the other types and have diameters of several hundred $\mu \mathrm{m}$. Tabular-shaped pores typically range from few tens to few $\mu \mathrm{m}$. The grains with colloform texture consist of micron-width wavy bright bands and darker matrix on BEI (Fig. 3d). The colloform grains contain void veins and irregular-shaped pores (Dong et al. 1995; Fig. 3d). Mosaic-textured grains consist of tens- $\mu \mathrm{m}$-sized equant interlocking quartz crystals. The crystalline rock fragments contain pores ranging from submicron to tens of $\mu \mathrm{m}$.

\section{Silica mineral-pyrite \pm alunite \pm kaolin-group mineral}

The association of silica mineral-pyrite \pm alunite \pm kaolin-group mineral is the most common of the ash grains. Grains with this assemblage appear as opaque whitecolored or opaque gray-colored under a binocular microscope. The original minerals have been completely replaced by silica mineral, alunite, kaolin-group mineral, rutile, and pyrite through hydrothermal alteration. The grains are classified into three types according to textures: pseudomorphic volcanic texture, fine-grained texture, and coarse mosaic texture. Grains with pseudomorphic 



Fig. $3 \mathrm{BEl}$ images of volcanic ash particles. a Typical partly altered volcanic fragments in the coarse fraction containing microlites of plagioclase, anorthoclase, sanidine, and minor interstitial glass. Some of plagioclase microlites and glass were replaced by pyrite, silica mineral, kaolin-group mineral, and muscovite. $\mathbf{b}$ The silica-pyrite assemblage in a grain containing darker pseudomorph in the matrix. Pyroxene phenocryst is replaced by silica mineral, and pyrite crystals fill the cleavage of the pseudomorphs. cThe right side of the grain partly retained the original vesicular texture, while the left part shows a completely deformed texture. Narrow veinlets of vug and pyrite crystals are recognized in the deformed part (arrow). d Grains containing silica-pyrite assemblage with colloform texture consisting of micron-width wavy bright bands and darker matrix. e Grain consisting of silica mineral, pyrite, alunite, kaolin-group mineral, showing pseudomorphic volcanic texture. Original crystals were replaced by silica mineral or kaolin (darker) or became void. f A silica minerals-pyrophyllite-pyrite assemblage grain comprises anhedral silica crystals (gray) and a fine-grained matrix of pyrophyllite (darker) 
volcanic texture are rich in vugs and preserve textures of the original volcanic rocks that are porphyritic, hyaloophitic, or hyalopilitic. Some vugs are rectangular in shape, indicating that the original crystals had been shed during the alteration, although some crystals have been replaced by silica mineral or kaolin (Fig. 3e). Other vugs are spherical, vein-like, and irregular in shape, ranging from a few to several hundred $\mu \mathrm{m}$. Pyrite and alunite crystals fill some of the vugs and cleavages of the pseudomorphic crystals. Grains with fine-grained texture show no sign of original rock texture but merely consist of fine-grained crystals. These grains are rich in $\mu \mathrm{m}$-size vugs that are spherical or irregular and contain densely distributed submicron vugs forming a spongy texture. The coarse mosaic texture consists of tens- to $\mu \mathrm{m}$-sized equant silica, euhedral to anhedral alunite, and intercrystalline voids. Flaky or massive crystals of alunite fill some of the voids.

\section{Silica minerals-pyrophyllite-pyrite}

The association of silica minerals, pyrophyllite, and pyrite is common, occurring as opaque gray-colored or transparent grains. The original texture is completely lost and the original minerals have been replaced by silica mineral, pyrophyllite, pyrite, and minor rutile. Some grains comprise anhedral silica crystals and fine-grained matrix of pyrophyllite (Fig. 3f). The silica mineral grains range from 1 to $100 \mu \mathrm{m}$ in size. Some silica grains contain abundant micron-sized spherical pores. The matrix pyrophyllite occurs as an aggregate of fine flaky crystal or very fine spongy texture dotted with euhedral pyrite crystals. The very fine matrix contains alligatoring voids. Some pyrophyllite-bearing grains consist solely of very fine-grained pyrophyllite with such voids.

\section{Silica minerals-muscovite}

The association of silica mineral-muscovite is common in the ash. The ash grains appear as opaque white grains under a binocular microscope. The original rock texture has been lost, and the minerals have been totally replaced by a mixture of fine crystals of silica mineral, muscovite, pyrite, and rutile. A peculiar muscovite-bearing grain, which appears as a translucent brownish gray-colored grain, contains chlorite and K-feldspar. The grain consists of coarse equant crystals of silica mineral, K-feldspar, and albite, forming equigranular texture, partly replaced by diffusively mottled chlorite and muscovite (Fig. 4a).

\section{Silica minerals-K-feldspar \pm albite \pm garnet \pm biotite}

The association of silica mineral-K-feldspar-albite-garnet occurs commonly in the ash. Grains with this assemblage appear as translucent white under a binocular microscope. Grains in this association are subdivided two types based on textures: the colloform texture (Dong et al. 1995: Fig. 4b) and the porous equigranular texture. The colloform texture consists of K-feldspar-rich bands and a fine-grained mixture of silica mineral and K-feldspar. The original texture has completely disappeared through replacement of altered minerals. The porous equigranular texture consists of tens- $\mu \mathrm{m}$-sized equant crystals of silica mineral, K-feldspar, and albite (Fig. 4b). The equigranular grains contain flaky biotite crystals in pores of the K-feldspar.

\section{Crystals of pyrite, anhydrite, and gypsum}

Free pyrite crystals are common in all size fractions. Euhedral pyrite crystals typically form aggregates ranging in size from a few micrometers to millimeters. Anhydrite-bearing grains are only observed in the medium fraction. Anhydrite occurs as $20-50-\mu \mathrm{m}$-size euhedral crystals. Some anhydrite crystals conjugate with grains of altered rock that belong to the silica-pyrite or silica-Kfeldspar \pm albite \pm garnet \pm biotite associations (Fig. 4c). The fine fraction contains fine $(<10 \mu \mathrm{m})$ euhedral alunite with hexagonal tabular or platy forms and tens- $\mu \mathrm{m}$-sized polyhedral crystals of gypsum (Fig. 4d).

\section{Discussion}

The volcanic ash is characterized by abundant hydrothermally altered rock fragments with different degrees of alteration and hydrothermally precipitated minerals. Juvenile material such as pumice, scoria, or glass shard was not found in the volcanic ash, whereas partly altered fragments consisting of primary igneous minerals (plagioclase, orthopyroxene, titanomagnetite, and feldspars), volcanic glass, and alteration minerals are common. Therefore, we conclude that the 2014 Ontake eruption was a non-juvenile eruption. Not all feldspars in the ash originate from fresh volcanic rock: Some were derived from the alteration zones. Plagioclase, anorthoclase, and alkali feldspar that coexist with volcanic glass in the partly altered volcanic rock fragments originate from fresh volcanic rocks, whereas K-feldspar and albite contained in the altered fragments of silica mineralK-feldspar \pm albite \pm garnet \pm biotite association were derived from hydrothermal alteration. Other than the remnant primary minerals, the volcanic ash contains quartz, tridymite, cristobalite, kaolin-group mineral, alunite, anhydrite, gypsum, pyrophyllite, muscovite, chlorite, K-feldspar, biotite, rutile, garnet, pyrite, and smectite. The mineral assemblage is typical of hydrothermal alteration zones in magmatic-hydrothermal systems under subduction zone volcanoes (Rye et al. 1992; Hedenquist and Lowenstern 1994). The mineral assemblages therefore indicate that the volcanic ash was derived from a subvolcanic hydrothermal system developed beneath the edifice of Ontake volcano. 

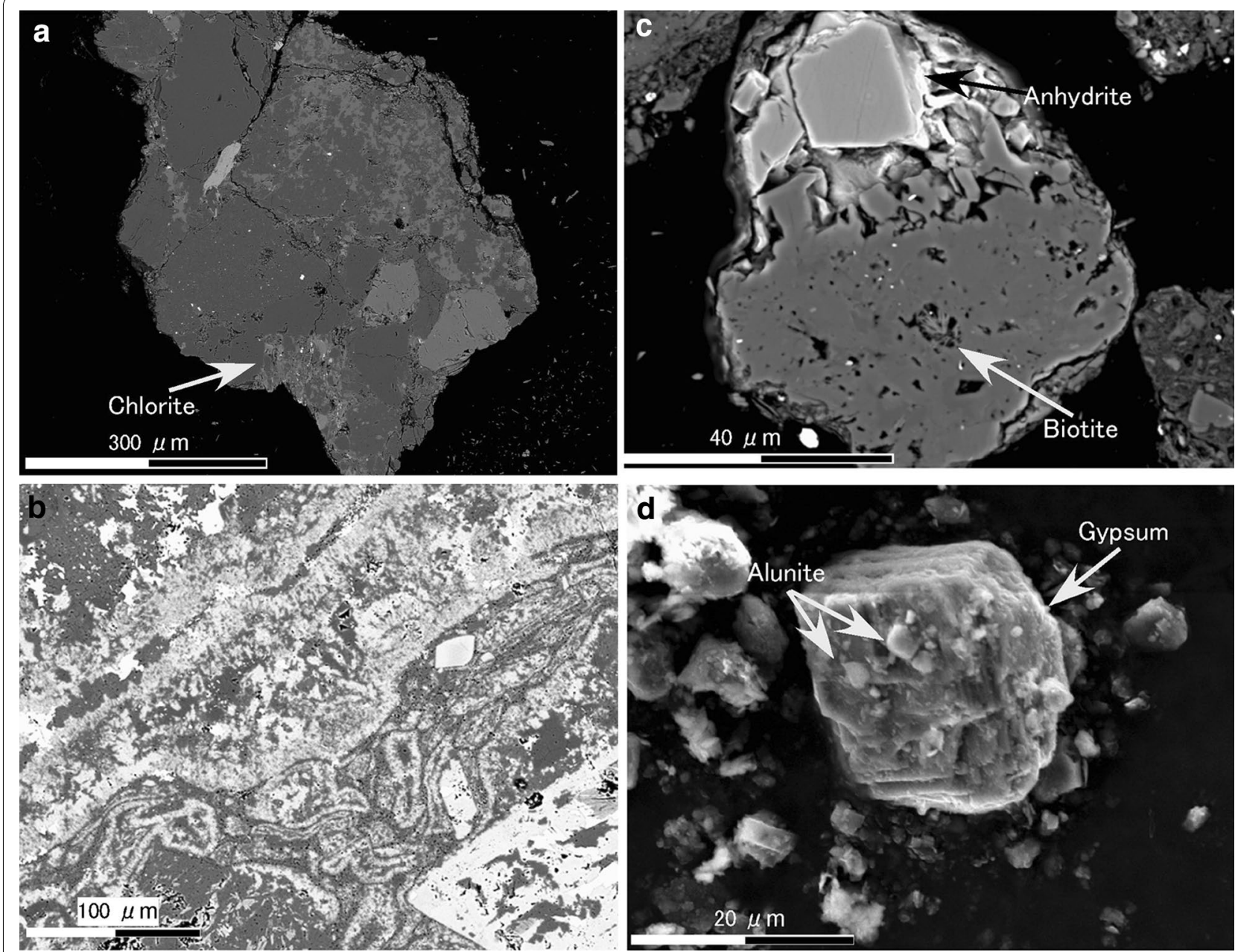

Fig. $4 \mathrm{BEl}$ images of volcanic ash particles. a A grain consisting of coarse equant crystals of silica mineral, K-feldspar, and albite, forming equigranular texture, partly replaced by diffusively mottled chlorite and muscovite. $\mathbf{b}$ Colloform texture in a grain consisting of silica minerals-K-feldspar. The colloform texture consists of K-feldspar-rich bands (brighter) and a fine-grained mixture of silica mineral and K-feldspar (darker). c Grain of altered rock that belongs to the silica-K-feldspar \pm albite \pm garnet \pm biotite assemblage in the medium fraction. The porous equigranular texture consists of tens- $\mu$ m-sized equant crystals of silica mineral, K-feldspar, and albite (darker). Anhydrite crystals (bright) are attached conjugate with the grain.

d The fine fraction consists of free euhedral crystals of alunite and gypsum

Five associations of alteration minerals were identified from observations on individual grains: silica-pyrite, silica-pyrite \pm alunite \pm kaolin, silica-pyrophyllite-pyrite, silica-muscovite, and silica $\pm \mathrm{K}$-feldspar \pm albite \pm garnet \pm biotite. The ash also contains free crystals of sulfide and sulfate minerals. Detailed mineralogy on these associations gives clues to the hydrothermal alteration processes and conditions. Abundant pores in pseudomorphic volcanic texture of grains from the silica-pyrite and silica-pyrite \pm alunite \pm kaolin associations (Fig. 3c, d) were presumably formed by defection of original crystals such as plagioclase and pyroxene during chemical leaching by highly acidic fluid, although some of pores probably reflect the original vesicular texture typically observed in volcanic rocks. Similar textures have been attributed to steam-heated volcanic environments and high-sulfidation ore systems in previous works (e.g., Giggenbach 1975; Stoffregen 1987; Rye et al. 1992). The textures and the dominance of the silica component imply that the silica-pyrite association is the residue of the leaching of other major cations from original rock, which has been termed vuggy silica alteration (Stoffregen 1987; Hedenquist et al. 2000). The associations of silicapyrite \pm alunite \pm kaolin and silica-pyrophyllite-pyrite shows textural evidence similar to advanced argillic type of alteration (Stoffregen 1987; Sillitoe 2010), wherein cations other than $\mathrm{Al}$ and $\mathrm{Si}$ are leached and accompanied by sulfate and sulfide precipitation. Two types of alteration that precipitate K-feldspar are suggested by the mineralogy of individual grains of the association of 
silica-K-feldspar \pm albite \pm garnet \pm biotite. The occurrence of flaky biotite in the pores of the equigranular ash grains indicates that this mineral precipitated from fluid. The paragenesis of K-feldspar (alkali feldspar with $\mathrm{Or}_{40-60}$ ) and the biotite represent full equilibration between a near-neutral hydrothermal fluid and host rock at high temperature $\left(>300{ }^{\circ} \mathrm{C}\right)$ (Giggenbach 1997), referred to as potassic alteration (Meyer and Hemley 1967). On the other hand, the colloform grains that lack biotite and the composition of the colloform-forming K-feldspar is the near-end member (Or > 97) which represents low-temperature crystallization. The K-feldspar colloform texture resembles typical altered rocks in hydrothermal veins of epithermal ore deposits (Fournier 1985; Saunders 1990). These characteristics imply that the colloform texture of this association was formed under full equilibrium conditions at low temperature $\left(<250{ }^{\circ} \mathrm{C}\right.$; Faure et al. 2002) in an epithermal environment.

The altered rock fragments in the ash indicate that the volcanic ash particles of the 2014 eruption of Ontake volcano were derived from different alteration zones distributed underneath the crater, including zones formed at a highly acidic condition (vuggy silica and advanced argillic zones) and at near-neutral conditions (sericite and potassic alterations). Although these zones could be distributed randomly, comparison with systematic spatial distribution models is worthwhile, because many studies have reported distribution models from different perspectives. The distribution models are based on studies of alteration zones surrounding porphyry copper ore deposits (e.g., Sillitoe 1973, 1999, 2010; Sillitoe and Gappe Jr 1984; Giggenbach 1997), active volcanoes (e.g., Ohba and Kitade 2005; John et al. 2008), and geothermal fields and epithermal ore deposits (e.g., Henley and Ellis 1983; Stoffregen 1987; Heald et al. 1987; Giggenbach 1997; Hedenquist et al. 2000).

These models commonly involve a silica-rich zone (vuggy silica), with accompanying aluminous hydrous sheet silicate minerals (kaolin and pyrophyllite) and alunite (advanced argillic alteration zone, lithocap) in the center top of a system. As applied to the porphyry copper model (Sillitoe 2010), the silica-pyrite, silicapyrite \pm alunite \pm kaolin, and silica-pyrophyllite zones are correlated with vuggy residual quartz/silicification, quartz-alunite and quartz-kaolinite zones, and the quartz-pyrophyllite zone, respectively. The association including K-feldspar implies hydrothermal alteration at near-neutral conditions, which can occur at different locations in hydrothermal systems. Some studies on volcanoes have found that neutralization of hydrothermal fluid tends to progress outward from the silicic core (vuggy silica alteration zone) through advanced argillic and argillic zones to propylitic alteration zones (Mt
Shimokura: Ohba and Kitade 2005; Mt Rainier: John et al. 2008) by analogy to the zonation in geothermal areas and epithermal ore fields (e.g., Henley and Ellis 1983; Kimbara 1983; Stoffregen 1987; Heald et al. 1987; Hedenquist et al. 2000). In those contexts, the propylitic alteration zone represents near-neutral conditions. On the other hand, neutralization in porphyry copper systems occurs below the advanced argillic alteration zone, and this type of alteration is referred to as potassic alteration (Giggenbach 1997; Sillitoe 2010). The paragenesis of alkali feldspar and hydrothermal biotite in the volcanic ash indicates high-temperature neutralization. This seems more likely to reflect the potassic alteration typical of porphyry copper systems, rather than neutralization at low temperature to form propylitic alteration that accompanies chlorite precipitation (Giggenbach 1997). According to the geologic models for porphyry copper systems, the potassic zone is located under the advanced argillic alteration zone (Giggenbach 1997; Sillitoe 2010). The Ontake volcanic ash contains few grains indicating the K-feldspar-bearing alteration (colloform texture) that potentially represents low-temperature conditions typical of epithermal ore deposits (Fournier 1985; Saunders 1990). The low-temperature neutral alteration might be locally distributed at shallow levels. The common occurrence of the silica-muscovite association supports a correlation between the volcanic ash and deep-seated neutral zones. In porphyry copper models, this association can be correlated with the sericite zone located between the silica-pyrophyllite zone and the potassic zone. We conclude that the volcanic ash of the 2014 Ontake eruption was derived from the magmatic-hydrothermal system that correlated well with the models for the porphyry copper system.

Here, the source depths of the volcanic ash particles are roughly estimated by correlating with the porphyry copper model by Sillitoe (2010), which shows a geologic structure in the late stage of porphyry system development. A late-stage porphyry system beneath Ontake volcano is assumed based on the association of alteration zones and the occurrence of anhydrite crystals attached to the grains of the silica-pyrite and silica-K-feldspar \pm albite \pm garnet \pm biotite associations. These occurrences are interpreted as fragments of altered rocks cut by anhydrite veinlets that represent a late-stage porphyry system (Fig. 5; Sillitoe 2010). In the model, the residual silica zone occurs from the surface to $\sim 1 \mathrm{~km}$ depth. The advanced argillic alteration zone ranges from the surface to $\sim 2 \mathrm{~km}$ (quartz-alunite zone: surface to $\sim 1 \mathrm{~km}$; quartz-pyrophyllite zone: $\sim 1$ to $\sim 2 \mathrm{~km}$ ). The sericite zone is situated at depths between $\sim 1.5$ and $\sim 2 \mathrm{~km}$, and the potassic zone is located deeper than $\sim 2 \mathrm{~km}$. Therefore, this correlation shows that the 


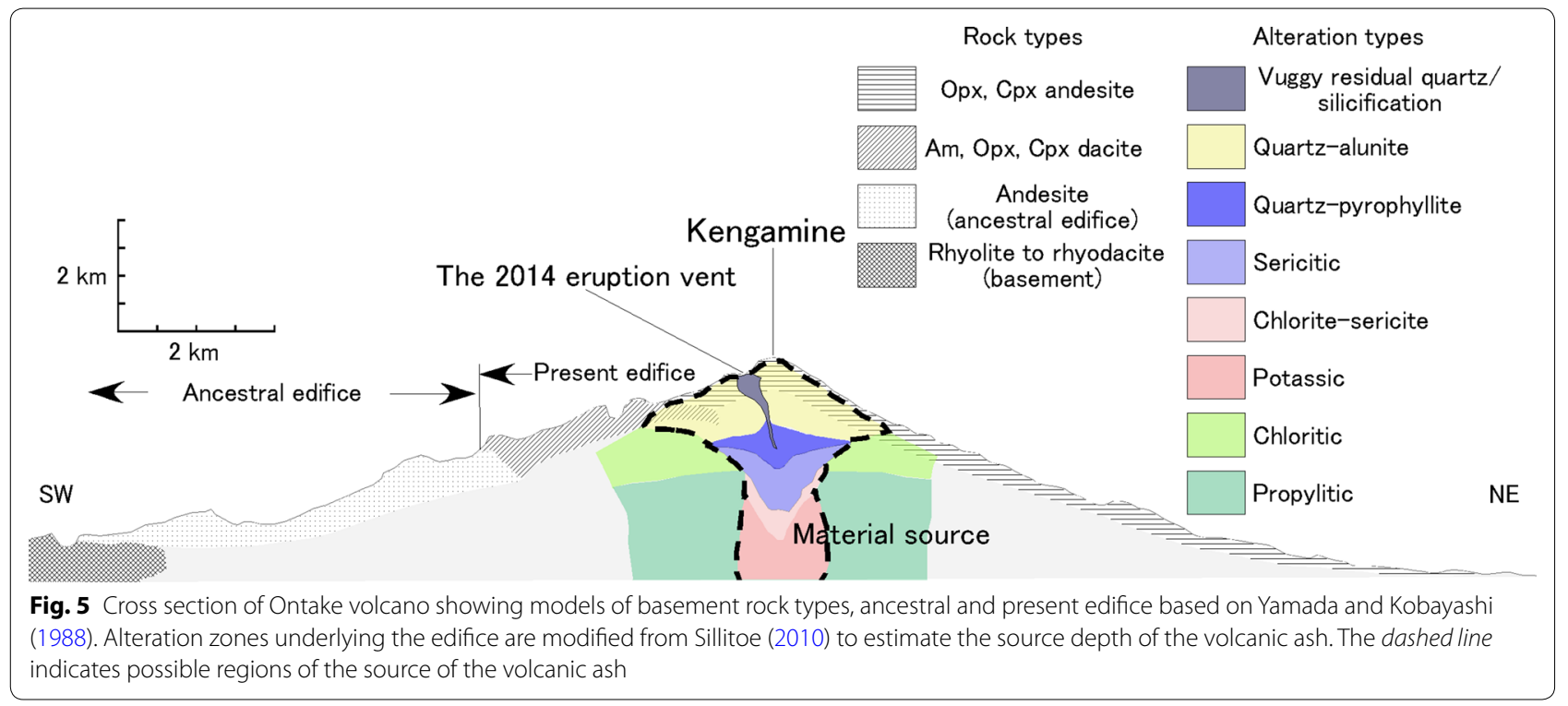

maximum source depth is $\sim 2 \mathrm{~km}$, but that the ash from shallow levels $(\sim 2 \mathrm{~km}$ to near the surface) is more abundant. The depths of hypocenters linked to the eruption are shallower than $3.5 \mathrm{~km}$ (Kato et al. 2015; Maeda et al. 2015). The shallow focal depths $(<3.5 \mathrm{~km})$ are roughly consistent with the source depths of volcanic ash.

Some types of ash grains are not involved in the correlation with porphyry copper models. The K-feldspar in the colloform-texture grains has Or-end member compositions that imply precipitation from low-temperature neutral fluid under epithermal conditions (Fournier 1985; Saunders 1990; Giggenbach 1997). Because epithermal alteration commonly develops at shallow levels above a deeper porphyry copper system (Henley and Ellis 1983; Sillitoe 1989, 2010; Giggenbach 1997; Sillitoe and Hedenquist 2003), the colloform-texture ash is under evidence of a shallow epithermal system overlying a deep porphyry system under Ontake volcano. Gypsum occurrence has been commonly reported from porphyry copper systems (e.g., Sillitoe 1973; Hezarkhani et al. 1999; Li et al. 2011), but has not been assigned in the mineral zonation model. Accordingly, we are not able to correlate gypsum occurrence with the model.

\section{Conclusions}

The volcanic ash of the eruption on September 27, 2014 at Ontake volcano was derived from the magmatichydrothermal system developed beneath the edifice. The mineralogy of the ash grains indicates the development of advanced argillic, sericite, and high-temperature potassic alteration zones. Associations of these alteration zones are correlated with those in late-stage porphyry copper systems. The comparison with the porphyry copper system estimates the depths of the advanced argillic, sericite, and potassic zones as 0 to $\sim 2, \sim 1.5$ to $\sim 2$, and $>2 \mathrm{~km}$, respectively. Therefore, the ash particles were derived from a maximum of $\sim 2 \mathrm{~km}$ depth and mainly from shallower levels ( $\sim 2 \mathrm{~km}$ to near the surface).

\section{Additional file}

Additional file 1. Mineral assemblages of altered rock fragments in the volcanic ash. All of mineral assemblages we obtained from the volcanic ash are shown. ${ }^{\dagger}$ : Minerals name are abbreviated as: Si: Silica mineral, Pyr: pyrite, Anh: anhydrite, Gyp: gypsum, Alu: alunite, Kao: $7 \AA$ A-kaolin-group mineral, Pyl: pyrophyllite, Mus: muscovite, Chl: chlorite, Bi: biotite, Grt: garnet, Kfs(Or): potassic feldspar with orthoclase percent in the bracket, $\mathrm{Ab}(\mathrm{Ab})$ : albite with albite percent the bracket, $\mathrm{PI}(\mathrm{An})$ : plagioclase with anorthite percent in the bracket, Ano(Ab): anorthoclase with albite percent the bracket, Px: pyroxene, and. Rul: rutile. ${ }^{+\dagger}$ : Samples named "coarse" is a grain in the coarse fraction and "med" is a grain in the medium fraction.

\section{Authors' contributions}

YM carried out the XRD analysis, the SEM-EDS analysis, and drafted the manuscript. TI carried out the field survey, the SEM-EDS analysis, and the XRD analysis. SH and TO conceived of the study, the field survey, carried out the SEM-EDS analysis, and participated in its design and coordination and drafted the manuscript. All authors read and approved the final manuscript.

\section{Author details}

${ }^{1}$ Graduate School of Engineering and Resource Science, Akita University, 1-1, Tegata Gakuenmachi, Akita 010-8502, Japan. ${ }^{2}$ Faculty of Education and Human Studies, Akita University, 1-1, Tegata Gakuenmachi, Akita 010-8502, Japan. ${ }^{3}$ Faculty of International Resource Sciences, Akita University, 1-1, Tegata Gakuenmachi, Akita 010-8502, Japan.

\section{Acknowledgements}

We gratefully acknowledge the discussions and significant technical support rendered by Prof. Akira Imai, Dr. Ryohei Takahashi, Dr. Hinako Sato, and Ms. Yumi Hayakawa of Akita University. We thank Dr. Kofi Adomako-Ansah and Ms. Jenielyn Tuando Padrones of Akita University for their proofreading of the manuscript. Reviews by two anonymous reviewers significantly improved the 
manuscript. This research was supported by Japan Society for the Promotion of Science (JSPS) leading program "New Frontier Leader Program for Rare-metals and Resources" and Japan Society for the Promotion of Science Grant-in-Aid for Scientific Research(C) 15K01245.

\section{Competing interests}

The authors declare that they have no competing interests.

Received: 3 December 2015 Accepted: 8 April 2016

Published online: 26 April 2016

\section{References}

Dong G, Morrison G, Jaireth S (1995) Quartz texture in epithermal veins, Queensland_-classification, origin and implication. Econ Geol 90:18411856. doi:10.2113/gsecongeo.90.6.1841

Earthquake Research Institute in the University of Tokyo (2014) http:// www.data.jma.go.jp/svd/vois/data/tokyo/STOCK/kaisetsu/CCPVE/ shiryo/130/130_no01.pdf. Accessed 4 Mar 2016

Faure K, Matsuhisa Y, Metsugi H, Mizota C, Hayashi S (2002) The Hishikari AuAg epithermal deposit, Japan: oxygen and hydrogen isotope evidence in determining the source of paleohydrothermal fluids. Econ Geol 97:481-498. doi:10.2113/gsecongeo.97.3.481

Fournier RO (1985) The behavior of silica in hydrothermal solution. Rev Econ Geol 2:45-62

Giggenbach WF (1975) The chemistry of Crater Lake, Mt. Ruapehu (New Zealand) During and after the 1971 active period. N Z J Sci 14:951-988

Giggenbach WF (1997) The origin and evolution of fluids in magmatic-hydrothermal systems. In: Barns HL (ed) Geochemistry of hydrothermal ore deposit, 3rd edn. Wiley, New York

Heald P, Foley NK, Hayba DO (1987) Comparative anatomy of volcanic-hosted epithermal deposits: acid-sulfate and adularia-sericite types. Econ Geol 82:1-26. doi:10.2113/gsecongeo.82.1.1

Hedenquist JW, Henley RW (1985) Hydrothermal eruptions in the Waiotapu geothermal system, New Zealand: their origin, associated breccias, and relation to precious metal mineralization. Econ Geol 80:1640-1668. doi:10.2113/gsecongeo.80.6.1640

Hedenquist JW, Lowenstern JB (1994) The role of magmas in the formation of hydrothermal ore deposits. Nature 370:519-527

Hedenquist JW, Arribas A, Gonzalez-Urien E (2000) Exploration for epithermal gold deposits. Rev Econ Geol 13:245-277

Henley RW, Ellis AJ (1983) Geothermal systems ancient and modern: a geochemical review. Earth Sci Rev 19:1-50

Hezarkhani A, Williams-Jones AE, Gammons CH (1999) Factors controlling copper solubility and chalcopyrite deposition in the Sungun porphyry copper deposit, Iran. Miner Depos 34:770-783. doi:10.1007/s001260050237

Japan Meteorological Agency (2014) Rep. Coordin. committee on prediction of volcanic eruption. http://www.data.jma.go.jp/svd/vois/data/tokyo/ STOCK/kaisetsu/CCPVE/shiryo/130/130_no01.pdf. Accessed 4 Mar 2016

John DA, Sisson TW, Breit GN, Rye RO, Vallance JW (2008) Characteristics, extent and origin of hydrothermal alteration at Mount Rainer Volcano, Cascades Arc, USA: implications for debris-flow hazards and mineral deposits. J Volcanol Geotherm Res 175:289-314

Kato A, Terakawa T, Yamanaka Y, Maeda Y, Horikawa S, Matsuhiro K, Okuda T (2015) Preparatory and precursory processes leading up to the 2014 phreatic eruption of Mount Ontake, Japan. Earth Planets Space 67:111. doi:10.1186/s40623-015-0288-x

Kimbara K (1983) Hydrothermal alteration and geothermal systems at the eastern part of Hachimantai. J Jpn Assoc Mineral Petrol Econ Geol 78:479-490 (in Japanese with English abstract)

Li G, Li J, Qin K, Duo J, Zhang T, Xiao B, Zhao J (2011) Geology and hydrothermal alteration of the Duobuza. Resour Geol 62:99-118. doi:10.1111/j.1751-3928.2011.00182.x

Maeda Y, Kato A, Terakawa T, Yamanaka Y, Horikawa S, Matsuhiro K, Okuda T (2015) Source mechanism of a VLP event immediately before the 2014 eruption of Mt. Ontake, Japan. Earth Planets Space 67:187. doi:10.1186/ s40623-015-0358-0

Meyer C, Hemley JJ (1967) Wall rock alteration at Butte, Montana. Am Mineral 50:1717-1722
Miyagi I, Geshi N, Hamasaki S, Tomiya A (2014) Volcanic ash particles from Ontake volcano on September 2014. In: Abstracts of the Volcanological Society of Japan the 2014 fall meeting, Fukuoka University, Fukuoka, 2-4 Nov 2014 (in Japanese)

Nakano S, Oikawa T, Yamasaki S, Kawanabe Y (2014) Distribution of craters and pyroclastic flows generated by eruption of Ontake volcano in September, 2014. In: Abstracts of the Volcanological Society of Japan the 2014 fall meeting, Fukuoka University, Fukuoka, 2-4 Nov 2014 (in Japanese)

Ogiso M, Matsubayashi H, Yamamoto T (2015) Descent of tremor source locations before the 2014 phreatic eruption of Ontake volcano, Japan. Earth Planets Space 67:206. doi:10.1186/s40623-015-0376-y

Ohba T, Kitade Y (2005) Subvolcanic hydrothermal systems: implication from hydrothermal minerals in hydrovolcanic ash. J Volcanol Geotherm Res 145:249-262

Ohba T, Hayashi S, Suzuki S, Kondo A, Kuzumaki T, Ogata T (2011) Chemical analysis of rock-forming minerals at Akita University: consistency of quantitative analytical results between SEM-EDX of Faculty of Education and Human Studies and WD-EPMA of Faculty of Engineering and Resource Science. Scientific and technical reports of Graduate School of Engineering and Resource Science, vol 32, Akita Univ, pp 1-6 (in Japanese with English abstract)

Oikawa T (2008) Reinvestigation of the historical eruption and fumarolic activity records at Ontake volcano, central Japan. Misunderstanding reports about the $774 \mathrm{AD}$ and $1892 \mathrm{AD}$ eruptions. Bull Geol Surv Jpn 59(5/6):203-221 (English abstract)

Oikawa T, Suzuki Y, Chiva T (2014) Eruption history and 2014 eruption of Ontake volcano. Kagaku 84(12):1218-1225 (in Japanese)

Reed HM (1997) Hydrothermal alteration and its relationship to ore fluid composition. In: Barnes HL (ed) Geochemistry of hydrothermal ore deposits, 3rd edn. Wiley, New York

Rose AW, Burt DM (1979) Hydrothermal alteration. In: Barnes HL (ed) Geochemistry of hydrothermal ore deposits, 2nd edn. Wiley, New York

Rye RO, Bethke PM, Wasserman MD (1992) The stable isotope geochemistry of acid sulfate alteration. Econ Geol 87:225-262. doi:10.2113/ gsecongeo.87.2.225

Saunders JA (1990) Colloidal transport of gold and silica in epithermal preciousmetal systems: evidence from the Sleeper deposit, Nevada. Geology 18:757-760. doi:10.1130/0091-7613(1990)018<0757:CTOGAS>2.3.CO;2

Sillitoe RH (1973) The top and bottoms of porphyry copper deposits. Econ Geol 68:799-815. doi:10.2113/gsecongeo.68.6.799

Sillitoe RH (1989) Gold deposits in western Pacific island arcs: the magmatic connection. Econ Geol Monogr 6:274-291

Sillitoe RH (1999) Styles of high-sulphidation gold, silver and copper mineralisation in porphyry and epirhermal environments. In: Pacrim'99 Congress, Bali, Indonesia, 1999, proceedings: Melbourne, Australasian Institute of Mining and Metallurgy, pp 29-44

Sillitoe RH (2000) Gold-rich porphyry deposits: descriptive and genetic models and their role in exploration and discovery. Rev Econ Geol 13:315-345

Sillitoe RH (2010) Porphyry copper systems. Econ Geol 105:3-41. doi:10.2113/ gsecongeo.105.1.3

Sillitoe RH, Gappe IM Jr (1984) Philippine porphyry copper deposits: geologic setting and characteristics: Bangkok, Thailand, United Nations ESCAP, CCOP Technical Publication 14

Sillitoe RH, Hedenquist JW (2003) Linkages between volcanotectonic settings, ore-fluid compositions, and epithermal precious metal deposits. Soc Econ Geol Spec Publ 10:315-343

Stoffregen R (1987) Genesis of acid-sulfate alteration and Au-Cu-Ag mineralization at Summitville, Colorado. Econ Geol 82:1575-1591. doi:10.2113/ gsecongeo.82.6.1575

Sugimoto T (2016) Kashmir 3D Ver 9.2.8 23819 (9.2.8). http://www.kashmir3d. com/. Accessed 19 Apr 2016

Takarada S, Oikawa T, Furukawa T, Hoshizumi H, Geshi N, Itoh J, Miyagi I (2014) Estimation of eruptive total mass of the Sep. 27, 2014 Ontake phreatic eruption. In: Abstracts of the Volcanological Society of Japan the 2014 fall meeting, Fukuoka University, Fukuoka, 2-4 Nov 2014 (in Japanese)

Takeuchi M, Nakano S, Harayama S, Otsuka T (1998) Geology of the KisoFukushima district. With Geological Sheet Map at 1:50,000, Geol. Surv. Jpn. (in Japanese with English abstract)

Yamada N, Kobayashi T (1988) Geology of the Ontakesan district. With Geological Sheet Map at 1:50,000, Geol. Surv. Jpn. (in Japanese with English abstract) 